\title{
Insufficient iodine intake in pregnant women in different regions of the world: a systematic review
}

1 Departamento de Nutrição e Saúde, Universidade Federal de Viçosa (UFV), Viçosa, MG, Brasil
Correspondence to:

Aline Carare Candido

Departamento de Nutrição e Saúde

Ed. Centro de Ciências Biológicas II

Av. Peter Henry Rolfs, $s / n^{\circ}$, Campus

Universitário

36570.900 - Viçosa, MG, Brasil

alinecarrare@gmail.com

Received on Dec/16/2018

Accepted on Apr/18/2019

DOI: 10.20945/2359-3997000000151

\author{
Aline C. Candido ${ }^{1}$ \\ http://orcid.org/0000-0002-6259-4786 \\ Núbia de S. de Morais ${ }^{1}$ \\ http://orcid.org/0000-0002-6457-3516 \\ Luiza V. Dutra ${ }^{1}$ \\ https://orcid.org/0000-0002-8351-655X \\ Carina A. Pinto' \\ http://orcid.org/0000-0002-1186-6702 \\ Sylvia do C. C. Franceschini ${ }^{1}$ \\ http://orcid.org/0000-0001-7934-4858 \\ Rita de Cássia G. Alfenas ${ }^{1}$ \\ http://orcid.org/0000-0003-2290-1611
}

\begin{abstract}
Objective: To determine the prevalence of insufficient iodine intake in pregnant women. Materials and methods: The search was performed in the electronic databases Medline (PubMed), Latin American and Caribbean Literature in Health Sciences (Lilacs) and Scopus. Review studies, experimental studies, those with adolescent pregnant women $(<20$ years) and iodine supplementation were excluded. The selection followed the steps of identifying the articles in the databases, deleting the duplicates, and reading the titles, abstracts, and then the entire article. The search for the articles occurred in September 2017, using the descriptors "pregnant" and "iodine deficiency" NOT "supplementation" in English, Portuguese and Spanish. Results: Thirteen articles were included, the deficiency prevalence ranged from $16.1 \%$ to $84.0 \%$, and the median of iodine intake was insufficient in $75 \%$ of the studies. There is no classification for mild, moderate or severe levels of iodine deficiency in pregnant women, which makes it impossible to know the real dimension of the problem. Conclusion: The high prevalence of insufficient iodine intake in pregnant women, observed worldwide, shows the need for a population classification in order to direct public policies. Arch Endocrinol Metab. 2019;63(3):306-11
\end{abstract}

Keywords

lodine deficiency; pregnant woman; prevalence

\section{INTRODUCTION}

$\mathrm{I}$ odine is essential for the synthesis of thyroid hormones during pregnancy and for the fetal neurological development (1-3) The main consequences of low intake for pregnant women are goiter, spontaneous abortion, hypothyroidism and thyroid nodules. And for the fetus it can result in neonatal hypothyroidism, cretinism, retardation in growth and neuropsychomotor development (4).

In pregnant women, the recommendation for iodine is higher because there is an increase in the production of thyroid hormone, renal losses and transfer of this mineral from the mother to the fetus, all of which increases the need (5).
The availability of iodine in nature differs by geographical area and deficiency is more associated with mountainous regions such as the Himalayas and Alps and areas with frequent flooding. In addition, other regions also have a scarcity of this mineral, such as Central Africa, Central Asia, Europe and in places where the soils are poor (6).

Universal salt iodination was suggested in 1831 by the French scientist Boussingault to minimize the prevalence of goiter. As a result, this strategy reduced goiter in the population, increased urinary excretion, improved thyroid function and increased iodine intake in pregnant women, so it was implemented in several countries around the world $(7,8)$. 
Based on this information, the identification of iodine deficient countries allows us to build a global structure for the formulation of targeted and effective public policies. Therefore, our goal is to determine the prevalence of insufficient iodine intake in pregnant women.

\section{MATERIALS AND METHODS}

The review followed the recommendations of the Preferred Reporting Items for Systematic Reviews (PRISMA) (9) and was based on the guiding question "Is there a reason for concern about insufficient iodine intake in pregnant women?".

The article search occurred in September 2017 without date delimitation. The authors independently searched the electronic databases Publisher Medline (PubMed), Latin American and Caribbean Literature in Health Sciences (Lilacs), and Scopus. Descriptors indexed in the Health Science Descriptors system (Decs) were combined as follows: "pregnant" AND "iodine deficiency" NOT "supplementation", in English, Portuguese and Spanish. For the PubMed search, we used the human, pregnant and adult filters, and in the Scopus filters, we used articles and pregnant women.

Original articles on the prevalence of insufficient iodine intake in adult pregnant women ( $\geq 20$ years) based on the Urinary Iodine Concentration (UIC), according to data from World Health Organization (WHO), were included (10). Review studies, experimental studies, those with adolescent pregnant women $(<20$ years old) and iodine supplementation were excluded. The selection followed the steps of identifying the articles in the databases, deleting the duplicates, and reading the titles, abstracts, and then the entire article.

The methodological quality of the studies was evaluated by the questionnaire proposed by Downs and Black (11), which contains 27 questions divided into four categories: study report (main findings described), external validity (evaluates representativeness), internal validity (investigates biases and confounding factors) and study power. We excluded 10 of the 27 questions since they referred to experimental studies. Each answer received a score of " 0 " (if it did not meet the criterion evaluated) or "l" (if the criterion was met), with a maximum of 17 points.

\section{RESULTS}

The search returned 469 articles. After eliminating duplicates by bases and among bases, 243 remained.
After reading titles, abstracts and articles in full, 13 were included (Figure 1).

The years of the studies ranged from 2010 to 2016, with three longitudinal and 10 cross-sectional studies, performed in North and South America (Venezuela and Canada), Africa (Democratic Republic of Congo), Asia (Japan, Iran, Turkey, Bangladesh, India), Europe (England and Spain), and Oceania (Australia).

The sample size ranged from 36 to 5,256 pregnant women and the prevalence of insufficient iodine intake ranged from 16.1 to $84.0 \%$. In order to evaluate the urinary iodine concentration (UIC) of pregnant women, the WHO reference was considered, where UIC $<150 \mu \mathrm{g} / \mathrm{L}$ is classified as insufficient iodine intake, $150-249 \mu \mathrm{g} / \mathrm{L}$ adequate, $250-499 \mu \mathrm{g} / \mathrm{L}$ more than necessary, $\geq 500 \mu \mathrm{g} / \mathrm{L}$ excessive intake (10).

Table 1 describes the results of the studies included in this review, with a median UIC ranging from 56.8 to $224.5 \mu \mathrm{g} / \mathrm{L}$. As described in Table 1 , we found that $75 \%(\mathrm{n}=9)$ of the studies were classified as insufficient iodine intake.

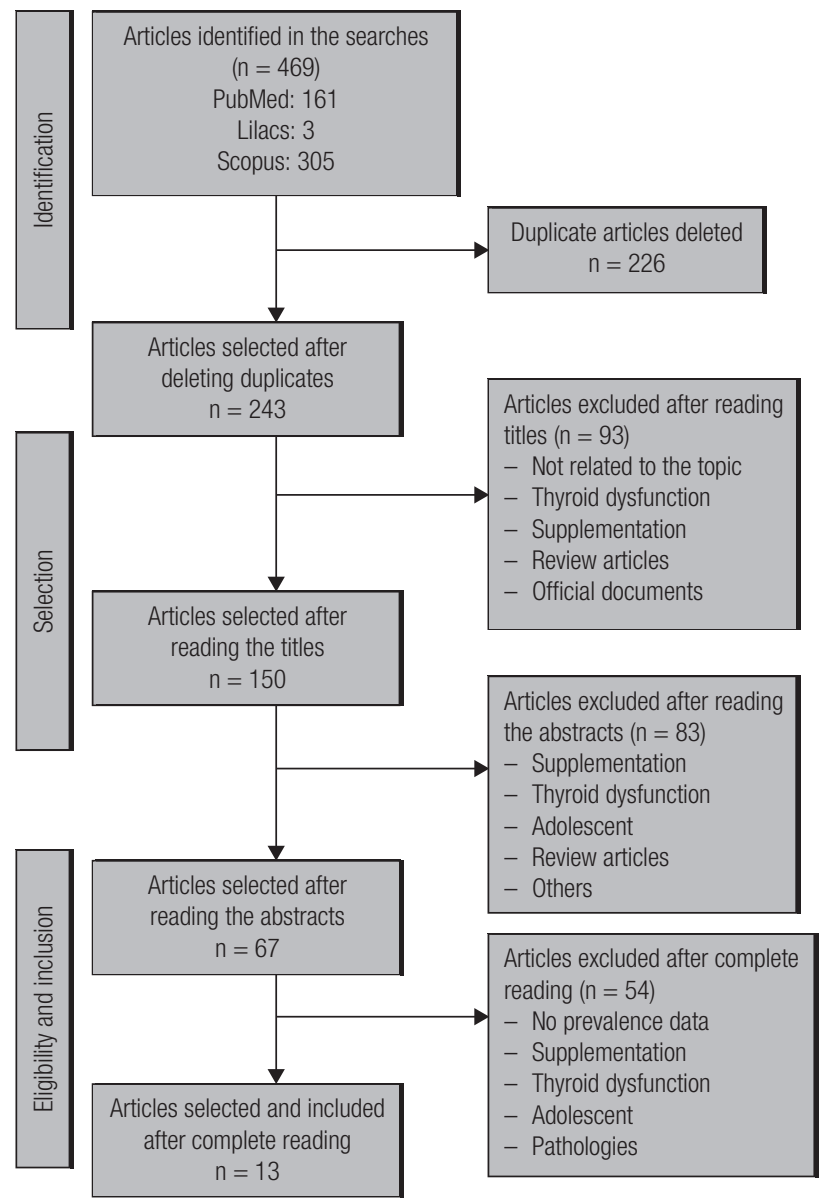

Figure 1. Flowchart of the process of identification and selection of the articles included. Source: PRISMA (9). 
Table 1. Description of the studies selected for systematic review

\begin{tabular}{|c|c|c|c|c|c|c|c|c|c|}
\hline $\begin{array}{c}\text { Authors / } \\
\text { Year }\end{array}$ & Site & $\begin{array}{c}\text { Study } \\
\text { Design }\end{array}$ & Recruitment & $\begin{array}{c}\text { Sample } \\
\text { size } \\
\text { (n) }\end{array}$ & $\begin{array}{l}\text { Trimester of } \\
\text { pregnancy }\end{array}$ & $\begin{array}{l}\text { Median Urinary } \\
\text { Iodine } \\
\text { Concentration } \\
\text { (UIC) ( } \mathrm{gg} / \mathrm{L})\end{array}$ & $\begin{array}{l}\text { Median UIC } \\
\text { Classification }\end{array}$ & $\begin{array}{c}\text { Prevalence } \\
\text { of lodine } \\
\text { Deficiency }\end{array}$ & $\begin{array}{l}\text { Quality of } \\
\text { the } \\
\text { Studies } \\
\text { Included }\end{array}$ \\
\hline $\begin{array}{l}\text { Nguyen and } \\
\text { cols. } \\
\text { (2010) (12) }\end{array}$ & Australia & $\begin{array}{l}\text { Cross- } \\
\text { sectional }\end{array}$ & $\begin{array}{l}\text { Pregnant women } \\
\text { from any } \\
\text { trimester of } \\
\text { gestation seen at } \\
\text { Canberra } \\
\text { Hospital, Australia }\end{array}$ & 100 & $\begin{array}{l}\text { The authors did } \\
\text { not mention the } \\
\text { trimester of } \\
\text { gestation }\end{array}$ & $62(12-750)$ & Insufficient & $84 \%$ & 12 points \\
\hline $\begin{array}{l}\text { Caballero } \\
(2011)(13)\end{array}$ & Venezuela & $\begin{array}{l}\text { Cross- } \\
\text { sectional }\end{array}$ & $\begin{array}{l}\text { Pregnant women } \\
\text { were selected at } \\
\text { the prenatal visit. } \\
\text { We selected } 300 \\
\text { pregnant women, } \\
100 \text { women from } \\
\text { each quarter }\end{array}$ & 300 & $\begin{array}{c}\text { First trimester } \\
(n=100), \text { second } \\
\text { trimester } \\
(n=100) \text { and } \\
\text { third trimester } \\
(n=100)\end{array}$ & 224.5 & Adequate & $25 \%$ & 14 points \\
\hline $\begin{array}{l}\text { Fuse and } \\
\text { cols. } \\
\text { (2011) (14) }\end{array}$ & Japan & $\begin{array}{l}\text { Cross- } \\
\text { sectional }\end{array}$ & $\begin{array}{l}\text { Healthy pregnant } \\
\text { women were } \\
\text { recruited during } \\
\text { the } 3 \text { quarters } \\
\text { and puerperal } \\
\text { with } 5 \text { to } 6 \text { weeks } \\
\text { postpartum } \\
\text { without history of } \\
\text { thyroid disease } \\
\text { attended at } \\
\text { Yamaguchi } \\
\text { Hospital, } \\
\text { Funabashi city }\end{array}$ & 934 & $\begin{array}{l}\text { First trimester } \\
\text { (n= 243), second } \\
\text { trimester } \\
(n=541) \text {, third } \\
\text { trimester } \\
(n=466) \text { and } \\
\text { postpartum } \\
(n=533)\end{array}$ & 219 & Adequate & $16.1 \%$ & 16 points \\
\hline $\begin{array}{l}\text { Çetinkaya } \\
\text { and cols. } \\
(2012)(15)\end{array}$ & Turkey & $\begin{array}{l}\text { Cross- } \\
\text { sectional }\end{array}$ & $\begin{array}{l}\text { We recruited } \\
\text { pregnant women } \\
\text { in the three } \\
\text { trimesters of } \\
\text { gestation at the } \\
\text { Medical University } \\
\text { of Ataturk, Turkey }\end{array}$ & 113 & $\begin{array}{c}\text { First trimester } \\
(n=30), \text { second } \\
\text { trimester }(n=49) \\
\text { and third } \\
\text { trimester }(n=34)\end{array}$ & $\begin{array}{c}132.8 \\
(15.1-291.6)\end{array}$ & Insufficient & $72.6 \%$ & 9 points \\
\hline $\begin{array}{l}\text { Shamim } \\
\text { and cols. } \\
(2012)(16)\end{array}$ & Bangladesh & $\begin{array}{l}\text { Cross- } \\
\text { sectional }\end{array}$ & $\begin{array}{c}\text { We recruit } \\
\text { pregnant women } \\
\text { from rural areas } \\
\text { in northwestern } \\
\text { Bangladesh. A } \\
\text { randomized, } \\
\text { placebo- } \\
\text { controlled study } \\
\text { with vitamin A or } \\
\text { beta-carotene } \\
\text { supplementation }\end{array}$ & 2490 & $\begin{array}{c}\text { First trimester } \\
(\leq 16 \text { weeks, } \\
n=1376) \text { and } \\
\text { third trimester } \\
(\geq 32 \text { weeks, } \\
n=1114)\end{array}$ & $\begin{array}{l}\text { Initial: } 66 \\
(34-133) \\
\text { Final: } 55 \\
(28-110)\end{array}$ & Insufficient & $\begin{array}{l}\text { Initial: } \\
\text { 78.85\% } \\
\text { Final: } \\
\text { 82.94\% }\end{array}$ & 16 points \\
\hline $\begin{array}{l}\text { Bath and } \\
\text { cols. } \\
(2013)(17)\end{array}$ & England & Longitudinal & $\begin{array}{l}\text { Pregnant women } \\
\text { living in the old } \\
\text { Avon area in } \\
\text { South West } \\
\text { England. }\end{array}$ & 1040 & $\begin{array}{l}\text { First trimester } \\
(<13 \text { weeks })\end{array}$ & $\begin{array}{c}91.1 \\
(53.8-143)\end{array}$ & Insufficient & $67 \%$ & 13 points \\
\hline $\begin{array}{l}\text { Aguayo and } \\
\text { cols. (2013) } \\
\text { (18) }\end{array}$ & Spain & Longitudinal & $\begin{array}{c}\text { Women attending } \\
\text { obstetric } \\
\text { outpatient } \\
\text { appointments in } \\
\text { the catchment } \\
\text { area of Cruces } \\
\text { Hospital }\end{array}$ & 2104 & $\begin{array}{c}\text { First trimester } \\
(n=2104) \text { and } \\
\text { second trimester } \\
(n=1322)\end{array}$ & $\begin{array}{c}\text { Quarter } \\
\text { 1st } 88.5 \\
(16-875) \\
\text { 2nd } 140 \\
(21-880)\end{array}$ & Insufficient & $\begin{array}{c}\text { Quarter } \\
\text { 1st }-79.8 \% \\
\text { 2nd }-54.4 \%\end{array}$ & 16 points \\
\hline
\end{tabular}




\begin{tabular}{|c|c|c|c|c|c|c|c|c|c|}
\hline $\begin{array}{c}\text { Authors / } \\
\text { Year }\end{array}$ & Site & $\begin{array}{c}\text { Study } \\
\text { Design }\end{array}$ & Recruitment & $\begin{array}{l}\text { Sample } \\
\text { size } \\
\text { (n) }\end{array}$ & $\begin{array}{l}\text { Trimester of } \\
\text { pregnancy }\end{array}$ & $\begin{array}{l}\text { Median Urinary } \\
\text { Iodine } \\
\text { Concentration } \\
\text { (UIC) ( } \mu \mathrm{g} / \mathrm{L})\end{array}$ & $\begin{array}{l}\text { Median UIC } \\
\text { Classification }\end{array}$ & $\begin{array}{c}\text { Prevalence } \\
\text { of lodine } \\
\text { Deficiency }\end{array}$ & $\begin{array}{c}\text { Quality of } \\
\text { the } \\
\text { Studies } \\
\text { Included }\end{array}$ \\
\hline $\begin{array}{l}\text { Amouzegar } \\
\text { and Azizi } \\
(2013)(19)\end{array}$ & Iran & $\begin{array}{l}\text { Cross- } \\
\text { sectional }\end{array}$ & $\begin{array}{l}\text { Pregnant women } \\
\text { referred to the } \\
\text { mother and child } \\
\text { health care clinics } \\
\text { of two maternity } \\
\text { hospitals of } \\
\text { Tehran }\end{array}$ & 36 & $\begin{array}{l}\text { First trimester } \\
(<15 \text { weeks })\end{array}$ & $\begin{array}{c}138.4 \\
(24.1-404)\end{array}$ & Insufficient & $34.0 \%$ & 16 points \\
\hline $\begin{array}{l}\text { Habimana } \\
\text { and cols. } \\
(2013)(20)\end{array}$ & $\begin{array}{l}\text { Democratic } \\
\text { Republic of } \\
\text { Congo }\end{array}$ & $\begin{array}{l}\text { Cross- } \\
\text { sectional }\end{array}$ & $\begin{array}{c}375 \text { pregnant } \\
\text { women attending } \\
\text { antenatal } \\
\text { consultation, } 125 \\
\text { women in each of } \\
\text { the three } \\
\text { maternity units }\end{array}$ & 225 & $\begin{array}{c}225 \text { pregnant } \\
\text { women in the } \\
\text { three quarters, } 75 \\
\text { women who gave } \\
\text { birth and } 75 \\
\text { non-pregnant } \\
\text { women as } \\
\text { controls }\end{array}$ & $138(105-172)$ & Insufficient & $52.3 \%$ & 13 points \\
\hline $\begin{array}{l}\text { Katz and } \\
\text { cols. } \\
(2013)(4)\end{array}$ & Canada & $\begin{array}{l}\text { Cross- } \\
\text { sectional }\end{array}$ & $\begin{array}{l}250 \text { pregnant } \\
\text { women from a } \\
\text { clinical hospital }\end{array}$ & 142 & $\begin{array}{l}\text { Second or third } \\
\text { trimester of a } \\
\text { singleton } \\
\text { pregnancy }\end{array}$ & $221(142-397)$ & Adequate & $29.6 \%$ & 12 points \\
\hline $\begin{array}{l}\text { Joshi and } \\
\text { cols. } \\
(2014)(21)\end{array}$ & India & $\begin{array}{l}\text { Cross- } \\
\text { sectional }\end{array}$ & $\begin{array}{l}\text { Pregnant women } \\
\qquad(\mathrm{n}=5256) \\
\text { attended the } \\
\text { Jamnabai General } \\
\text { Hospital. }\end{array}$ & 5.256 & $\begin{array}{l}\text { First trimester } \\
(<15 \text { weeks })\end{array}$ & 297,14 & $\begin{array}{l}\text { More than } \\
\text { necessary }\end{array}$ & $16.79 \%$ & 10 points \\
\hline $\begin{array}{l}\text { Bath and } \\
\text { cols. } \\
(2015)(22)\end{array}$ & England & Longitudinal & $\begin{array}{l}230 \text { British } \\
\text { pregnant women } \\
\text { recruited for the } \\
\text { Selenium in } \\
\text { Pregnancy } \\
\text { intervention }\end{array}$ & 230 & $\begin{array}{l}\text { Pregnant women } \\
\text { in the first } \\
\text { trimester (12-14 } \\
\text { weeks), second } \\
\text { trimester (20 } \\
\text { weeks) and third } \\
\text { trimester } \\
\text { (35 weeks) }\end{array}$ & $\begin{array}{c}56.8 \\
(31.1-104)\end{array}$ & Insufficient & $55.7 \%$ & 15 points \\
\hline $\begin{array}{l}\text { Delshad } \\
\text { and cols. } \\
\text { (2016) (23) }\end{array}$ & Iran & $\begin{array}{l}\text { Cross- } \\
\text { sectional }\end{array}$ & $\begin{array}{l}\text { Pregnant women } \\
\text { attended at } \\
\text { maternal and } \\
\text { child health } \\
\text { centers }\end{array}$ & 1072 & $\begin{array}{l}\text { Singleton } \\
\text { pregnancy and in } \\
\text { the first, second } \\
\text { and third } \\
\text { trimester of their } \\
\text { pregnancy }\end{array}$ & $\begin{array}{c}87.3 \\
(43.5-139.1)\end{array}$ & Insufficient & $78.17 \%$ & 10 points \\
\hline
\end{tabular}

In the evaluation of the methodological quality of the studies, the lowest score was nine and the highest 16. The best-evaluated criteria were the study report (main findings described), external validity (the same follow-up time for all individuals, appropriate statistical tests, and outcomes with reliable measures) and internal validity (individuals recruited in the same period). Only two studies presented power and adjustment for confounding factors in the analysis.

\section{DISCUSSION}

Insufficient iodine intake is an obstacle to social and economic development, reaching approximately
2 billion people worldwide (10). To eradicate the disorders caused by deficiency, universal iodination of salt is used as a safe, economical and sustainable strategy to ensure adequate intake worldwide (24).

Globally, $86.6 \%$ of households have access to iodized salt, with the number of people consuming it increasing from 1 billion to approximately 4 billion in the last 10 years (25) In this study, of the evaluated countries, Japan has no legislation for salt iodination, in England and Spain, it is voluntary, and it is mandatory in the others.

The highest prevalence of deficiency detected was in Australia (84\%), located in Oceania, different from expected, since there is a mandatory salt iodization 
policy and is surrounded by the Indian and Pacific oceans. However, natural disasters are recurrent in that country, and iodine deficiency can be an ecological phenomenon caused by flooding and soil erosion and, consequently, food crops will be deficient (4).

Asian countries: Turkey, Bangladesh and Iran showed insufficient iodine intake in pregnant women. Despite the extensive territory, the exponential growth of the population has led to a shortage of basic survival conditions, making access to adequate food difficult. This deficiency may also be a reflection of geographic characteristics such as mountains, floodplains and distance from the sea, restricting access to iodine sources. ${ }^{10}$ However, in India, iodine intake was more than necessary, demonstrating that monitoring salt iodization is critical, since overeating can be detrimental to health (21).

In contrast, the lower prevalence of deficiency was observed in Japan, which has no legislation for salt iodization. However, the habit of ingesting dietary sources of iodine, without subjecting them to high temperatures, may justify adequate population status (26).

Studies in European countries, England and Spain, found insufficient intake. The authors attributed this result to variations in the consumption of dietary sources of iodine and to the fact that pregnant women did not receive supplementation $(18,22)$.

In Venezuela and Canada, located in South and North America, iodine intake was adequate, demonstrating the success of awareness campaigns conducted in these countries for the consumption of iodized salt to protect the mother from health problems $(4,13)$.

At the 60th WHO World Health Assembly in 2007, about $31 \%$ of the world population had insufficient iodine intake and the most affected regions were Asia and Europe, while in the Americas the intake of fortified salt ensured adequate iodine status (25).

In Africa, a study in the Democratic Republic of Congo found insufficient iodine intake in the semiurban and rural region, reflecting low socioeconomic status and population location, making access to iodine sources difficult. In addition, in the rural area, the habit of using natural spices instead of fortified salt contributes to this deficiency $(20)$.

The difference in the prevalence of insufficient iodine intake can be attributed to geographic characteristics, dietary habits and salt iodination policy. This study was geographically representative allowing an overview of the prevalence of insufficient iodine intake in pregnant women in different regions of the world: the overall state of iodine in pregnant women.
The limitation is that the classification for levels of mild, moderate or severe iodine deficiency in pregnant women is not defined, making it impossible to know the magnitude of the problem.

In conclusion, pregnant women are a group vulnerable to insufficient iodine intake and the high prevalence observed in this review confirms the severity of this health problem worldwide. Therefore, there is a need for a population classification to guide public policies, as well as strategies such as salt iodization that should receive government support, and an effective monitoring to ensure adequate iodine intake.

Acknowledgements: this study was financed in part by the Coordenação de Aperfeiçoamento de Pessoal de Nivel Superior - Brasil (CAPES) - Finance Code 001; the Conselho Nacional de Desenvolvimento Científico e Tecnológico (CNPq), process 408295/20171 and the Fundação de Amparo à Pesquisa do Estado de Minas Gerais (FAPEMIG) process APQ-03336-18.

Funding Source: this study was financed in part by the Coordenação de Aperfeiçoamento de Pessoal de Nivel Superior Brasil (CAPES) - Finance Code 001; the Conselho Nacional de Desenvolvimento Cientifico e Tecnológico (CNPq), process 408295/2017-1 and the Fundação de Amparo à Pesquisa do Estado de Minas Gerais (FAPEMIG) process APQ-03336-18.

Disclosure: no potential conflict of interest relevant to this article was reported.

\section{REFERENCES}

1. Calvo RM, Jauniaux E, Gulbis B, Asunción M, Gervy C, Contempré $B$, et al. Fetal tissues are exposed to biologically relevant free thyroxine concentrations during early phases of development. J Clin Endocrinol Metab. 2002;87(4):1768-77.

2. Morreale de Escobar G, Obregon MJ, Escobar del Rey F. Role of thyroid hormone during early brain development. Eur $\mathrm{J}$ Endocrinol [Internet]. 2004;(Suppl 3):U25-37.

3. Teixeira D, Calhau C, Pestana D, Vicente L, Graça P. lodo Importância para a saúde e o papel da alimentação. Programa Nacional para a Promoção da Alimentação Saudável - DireçãoGeral da Saúde; 2014.

4. Katz PM, Leung AM, Braverman LE, Pearce EM, Tomlinson G, He $X$, et al. lodine Nutrition During Pregnancy In Toronto, Canada. Endocr Pract. 2013;19(2):206-11.

5. Lazarus JH. Thyroid disease in relation to pregnancy: A decade of change. Clin Endocrinol (Oxf) [Internet]. 2000;53(3):265-78.

6. Linhares DPS, Garcia PV, Almada A, Ferreira T, Queiroz G, Cruz $\mathrm{JV}$, et al. lodine environmental availability and human intake in oceanic islands: Azores as a case-study. Sci Total Environ. 2015 Dec 15;538:531-8.

7. Knobel M, Medeiros-Neto G. Moléstias associadas à carência crônica de iodo. Arq Bras Endocrinol Metabol. 2004;48(1):53-61.

8. Pontes AAN De, Rocha ADM, Leite DFB, Lessa ADF, Adan LFF. lodization of salt in Brazil, a controversial subject. Arq Bras Endocrinol Metabol. 2009;53(1):113-4.

9. Liberati A, Altman DG, Tetzlaff J, Mulrow C, Gøtzsche PC, loannidis JPA, et al. The PRISMA statement for reporting systematic 
reviews and meta-analyses of studies that evaluate healthcare interventions: Explanation and elaboration. BMJ. 2009 Jul 21;339:b2700.

10. WHO. Assessment of the iodine deficiency disorders and monitoring their elimination. World Heal Organ (WHO), Geneva [Internet]. 2007;3:1-107.

11. Downs SH, Black N. The feasibility of creating a checklist for the assessment of the methodological quality both of randomised and non-randomised studies of health care interventions. J Epidemiol Community Health. 1998;52(6):377-84.

12. Nguyen B, Baker D, Southcott E, Potter J, Sneddon A, Hickman PE. lodine deficiency in pregnant women in the ACT. Aust New Zeal J Obstet Gynaecol. 2010;50(6):539-42.

13. Caballero L. Yoduria en escolares y embarazadas del estado Trujillo, Venezuela 2007-2008 Urinary lodine in school children and pregnant women ofTrujillo state, Venezuela 2007-2008. Raem No. 2011;48(4):206-11.

14. Fuse $Y$, Ohashi $T$, Yamaguchi $S$, Yamaguchi M, Shishiba $Y$, Irie M. lodine status of pregnant and postpartum Japanese women: Effect of iodine intake on maternal and neonatal thyroid function in an iodine-sufficient area. J Clin Endocrinol Metab. 2011;96(12):3846-54.

15. Çetinkaya $K$, Ingeç M, Çetinkaya S, Kaplan I. lodine defi ciency in pregnancy and in women of reproductive age in Erzurum, Turkey. 2012;42(4):675-80.

16. Shamim A, Parul C, Schulze K, Ali H, Alamgir K, Rashid M, et al. lodine status in pregnancy and household salt iodine content in rural Bangladesh. Matern Child Nutr. 2012;8(2):162-73.

17. Bath SC, Steer CD, Golding J, Emmett P, Rayman MP. Effect of inadequate iodine status in UK pregnant women on cognitive outcomes in their children: Results from the Avon Longitudinal Study of Parents and Children (ALSPAC). Lancet [Internet]. 2013;382(9889):331-7.
18. Aguayo A, Grau G, Vela A, Aniel-Quiroga A, Espada M, Martul P, et al. Urinary iodine and thyroid function in a population of healthy pregnant women in the North of Spain. J Trace Elem Med Biol. 2013;27(4):302-6.

19. Amouzegar A, Azizi F. Variations of urinary iodine during the first trimester of pregnancy in an iodine-replete area. Comparison with non-pregnant women. Hormones. 2013;12(1):111-8.

20. Habimana L, Twite KE, Wallemacq $P$, De Nayer $P$, Daumerie $C$, Donnen $\mathrm{P}$, et al. lodine and iron status of pregnant women in Lubumbashi, Democratic Republic of Congo. Public Health Nutr. 2013;16(8):1362-70.

21. Joshi K, Nair S, Khade C, Rajan MGR. Early gestation screening of pregnant women for iodine deficiency disorders and iron deficiency in urban centre in Vadodara, Gujarat, India. J Dev Orig Health Dis [Internet]. 2014;5(01):63-8.

22. Bath SC, Furmidge-Owen VL, Redman CW, Rayman MP. Gestational changes in iodine status in a cohort study of pregnant women from the United Kingdom: season as an effect modifier. Am J Clin Nutr. 2015;101(6):1180-7.

23. Delshad H, Touhidi M, Abdollahi Z, Hedayati M, Salehi F, Azizi F. Inadequate iodine nutrition of pregnant women in an area of iodine sufficiency. J Endocrinol Invest. 2016;39(7):755-62.

24. World Health Organization (WHO). World Summit for Children - Mid-Decade Goal: lodine Deficiency Disorders (Idd). UNICEFWHO Jt Comm Heal Policy Spec Sess. 1994;2(27):27-8.

25. Pretell E. Boletim de Carências Nutricionais: Distúrbios por Deficiência de lodo - DDI. Ministério da Saúde. Secretaria de Atenção à Saúde Política de Alimentação e Nutrição (CGPAN). 2008; 1: 1-6.

26. Fisher J, Tran T, Biggs B, Tran T, Dwyer T, Casey G, et al. lodine status in late pregnancy and psychosocial determinants of iodized salt use in rural northern Viet Nam. Bull World Health Organ. 2011;89(11):813-20. 


\section{Insufficient iodine intake in pregnant women in different regions of the world: a systematic review}

DOI: 10.20945/2359-3997000000151

Arch Endocrinol Metab. 2019;63(3):306-11

Where you read:

Table 1. Description of the studies selected for systematic review

\begin{tabular}{|c|c|c|c|c|c|c|c|c|c|}
\hline $\begin{array}{c}\text { Authors I } \\
\text { Year }\end{array}$ & Site & $\begin{array}{l}\text { Study } \\
\text { Design }\end{array}$ & Recruitment & $\begin{array}{l}\text { Sample } \\
\text { size } \\
\text { (n) }\end{array}$ & $\begin{array}{l}\text { Trimester of } \\
\text { pregnancy }\end{array}$ & $\begin{array}{l}\text { Median Urinary } \\
\text { Iodine } \\
\text { Concentration } \\
\text { (UIC) }(\mu \mathrm{g} / \mathrm{L})\end{array}$ & $\begin{array}{c}\text { Median UIC } \\
\text { Classification }\end{array}$ & $\begin{array}{c}\text { Prevalence } \\
\text { of lodine } \\
\text { Deficiency }\end{array}$ & $\begin{array}{c}\text { Quality of } \\
\text { the } \\
\text { Studies } \\
\text { Included }\end{array}$ \\
\hline $\begin{array}{l}\text { Amouzegar } \\
\text { and Azizi } \\
\text { (2013) (19) }\end{array}$ & Turkey & $\begin{array}{l}\text { Cross- } \\
\text { sectional }\end{array}$ & $\begin{array}{l}\text { Pregnant women } \\
\text { referred to the } \\
\text { mother and child } \\
\text { health care clinics } \\
\text { of two maternity } \\
\text { hospitals of } \\
\text { Tehran }\end{array}$ & 36 & $\begin{array}{l}\text { First trimester } \\
(<15 \text { weeks) }\end{array}$ & $\begin{array}{c}138.4 \\
(24.1-404)\end{array}$ & Insufficient & $34.0 \%$ & 16 points \\
\hline
\end{tabular}

Should read:

Table 1. Description of the studies selected for systematic review

\begin{tabular}{|c|c|c|c|c|c|c|c|c|c|}
\hline $\begin{array}{c}\text { Authors I } \\
\text { Year }\end{array}$ & Site & $\begin{array}{l}\text { Study } \\
\text { Design }\end{array}$ & Recruitment & $\begin{array}{c}\text { Sample } \\
\text { size } \\
\text { (n) }\end{array}$ & $\begin{array}{l}\text { Trimester of } \\
\text { pregnancy }\end{array}$ & $\begin{array}{l}\text { Median Urinary } \\
\text { Iodine } \\
\text { Concentration } \\
\text { (UIC) }(\mu \mathrm{g} / \mathrm{L})\end{array}$ & $\begin{array}{l}\text { Median UIC } \\
\text { Classification }\end{array}$ & $\begin{array}{c}\text { Prevalence } \\
\text { of lodine } \\
\text { Deficiency }\end{array}$ & $\begin{array}{c}\text { Quality of } \\
\text { the } \\
\text { Studies } \\
\text { Included }\end{array}$ \\
\hline $\begin{array}{l}\text { Amouzegar } \\
\text { and Azizi } \\
\text { (2013) (19) }\end{array}$ & Iran & $\begin{array}{l}\text { Cross- } \\
\text { sectional }\end{array}$ & $\begin{array}{l}\text { Pregnant women } \\
\text { referred to the } \\
\text { mother and child } \\
\text { health care clinics } \\
\text { of two maternity } \\
\text { hospitals of } \\
\text { Tehran }\end{array}$ & 36 & $\begin{array}{l}\text { First trimester } \\
(<15 \text { weeks) }\end{array}$ & $\begin{array}{c}138.4 \\
(24.1-404)\end{array}$ & Insufficient & $34.0 \%$ & 16 points \\
\hline
\end{tabular}

